\title{
Eksistensi Ritus Gawe Pati Pada Masyarakat Wetu Telu di Dusun Bayan Beleq, Desa Bayan, Kecamatan Bayan, Kabupaten Lombok Utara
}

\author{
Eka Trisma Hidayanti ${ }^{1}$, I Gusti Putu Sudiarna ${ }^{2}$ \\ ${ }^{[12]}$ Prodi Antropologi Fakultas Ilmu Budaya Unud \\ [1ekatrishidayanti@gmail.com] [2[igpsudiarna@yahoo.co.id] \\ *Corresponding Author
}

\begin{abstract}
Abstrak
Wetu Telu people has a life passage rite which is a very sacred gawe pati rite and associated with the ancestor. Gawe pati is a rite for care of the corpses performed with custom and very different from other Lombok society. The aims of this research are to know: (a) how the implementation of gawe pati rite in Wetu Telu of Bayan Village and (b) how is the existence of gawe pati rite in Wetu Telu community. The implementation and existence of the gawe pati rite in the Wetu Telu community can be studied through the transitional rite theory A. Van Gennep and Malinowski's functionalist theory. This study uses ethnographic research methods that include data that is qualitative. The result of research is gawe pati implementation starting with Selamet Gumi nyusur tanak until nyiu as the closing of the gawe pati procession. Furthermore, the reason for the people of Wetu Telu still maintain the gawe pati rite because they believe in the blessing of the ancestors. The soul of dead relatives will have a good place in the noble realm and can give God blessing to living relatives. The existence of this rite is supported by the existence of internal an eksternal factors. In addition to the factors that support the creation of gawe pati rite, there is also a challenge factor in maintaining the existence of gawe pati rite.
\end{abstract}

Keywords: Wetu Telu, transitional rites, gawe pati

\section{Latar Belakang}

Indonesia memiliki beragam budaya yang berada di hampir setiap daerah. Identitas kebersamaan dalam bentuk budaya yang mengikat masyarakat perlahan mulai merenggang dan luntur akibat adanya modernisasi dan gerakan pemurnian agama yang perlahan mengakibatkan lunturnya kebudayaan nenek moyang. Namun, tidak semua masyarakat daerah mudah melepaskan kebudayaan mereka meskipun modernisasi dan pemurnian agama telah mereka rasakan. Mereka menganggap budaya tersebut merupakan kebiasaan yang tetap harus dipertahankan meskipun telah mengalami tantangan.

Tantangan mempertaankan identitas dan eksistensi kebudayaan yang dimiliki biasanya tidak hanya datang dari luar, namun terkadang terdapat tantangan dari dalam masyarakat itu sendiri seperti peralatan yang sudah jarang ditemukan pada masa modern, sulitnya menyatukan masyarakat yang biasanya keluar desa atau kota untuk bekerja, serta masalah internal yang paling dominan adalah biaya pelestarian atau perayaan budaya untuk menunjukkan identitas dan eksistensi masyarakat untuk meneruskan budaya nenek moyang.

Selain tantangan dari dalam, terdapat tantangan dari luar seperti kuatnya arus modernisasi dan gencarnya gerakan pemurnian agama hingga ke pelosok desa di Indonesia. Namun terdapat beberapa masyarakat yang masih memilih untuk mempertahankan warisan 
budaya, salah satunya pada masyarakat Wetu Telu yang terdapat di Dusun Bayan Beleq, Desa Bayan, Kecamatan Bayan, Kabupaten Lombok Utara. Masyarakat Wetu Telu di Desa Bayan terutama Dusun Bayan Beleq yang terdiri dari gabungan tiga dusun yaitu Dusun Bayan Timur, Dusun Bayan Barat, dan Dusun Karangbajo sangat berbeda dengan Suku Sasak pada umumnya karena masih mempertahankan kebudayaan yang terangkum dalam aturan adat yang wajib masyarakat ikuti sebagai pedoman hidup.

Masyarakat penganut Wetu Telu diidentikkan dengan masyarakat yang dalam praktek kehidupan sehari-hari sangat kuat berpegang kepada adatistiadat nenek moyang. Islam mainstrem atau Islam Waktu Lima berpandangan bahwa kurang sempurnanya model peribadatan masyarakat Wetu Telu disebabkan karena mereka terbenam dalam praktik adat, terutama praktek kuno pemujaan leluhur yang diturunkan serta sarat dengan animisme. (Budiwanti, 2000). Namun menurut penganutnya, Wetu Telu adalah falsafah kehidupan.Falsafah hidup yang diajarkan dalam kepercayaan Wetu Telu mengandung nuansa Islam mainstream namun lebih dimaknakan dalam aturan adat.

Konsep hidup yang dinamakan falsafah Wetu Telu ini mengingatkan pada konsep Tri Hita Karana yang dikenal dalam ajaran Hindu (Umam,dkk, 2006). Masyarakat Wetu Telu mengakui roh leluhur dan juga makhluk halus yang menempati benda-benda mati dan memiliki kekuatan supranatural, karena itulah masyarakat Wetu Telu masih melakukan ritual untuk tetap terhubung dengan roh leluhur. Masyarakat Dusun Bayan Beleq meyakini bahwa setiap orang yang mengalami kematian akan menjadi leluhur jika keturunannya mampu membekali perjalanan roh untuk menuju alam keluhuran melalui ritus gawe pati. Ritus gawe pati dilaksanakan dengan menggabungkan antara tata cara agama dan adat. Keduanya berjalan beriringan seperti tidak dapat dipisahkan seperti dalam satu ritual menshalatkan mayat misalnya, bacaan dan rukun shalat memakai cara agama, namun kyai harus memakai pakaian adat, membakar kemenyan, serta terlebih dahulu mengunyah pinang dan sirih.

Malam hari dalam memperingati tiga hari pasca kematian sampai seribu hari, para kyai membaca Al-Qur'an diselingi dengan minum brem atau minuman fermentasi dari tape ketan yang dapat memabukkan jika dikonsumsi secara berlebihan. Adanya arus globalisasi yang kuat akibat perkembangan pariwisata di Lombok Utara dan gencarnya gerakan pemurnian Islam yang dilakukan oleh Tuan Guru di Lombok tidak membuat masyarakat Dusun Bayan Beleq meninggalkan praktek keagamaan yang telah diyakini sejak lama, meskipun pengaruh keberadaan Tuan Guru mampu memberikan sedikit dampak perubahan pada praktek keagamaan ritus gawe pati, namun hingga sekarang ritus tersebut masih disakralkan pelaksanaannya karena masyarakat Dusun Bayan Beleq mampu menjaga eksistensinya.

Masyarakat Dusun Bayan Beleq tetap melestarikan tradisi turun temurun mereka baik untuk ritus gawe urip dan gawe pati. Hal inilah yang menjadi permasalahan menarik untuk dikaji karena keberadaan Wetu Telu saat ini bukan semata-mata hasil warisan saja, melainkan juga merupakan hasil dari keteguhan hati masyarakat Dusun Bayan Beleq untuk mempertahankan budaya. Bertolak dari berbagai paparan diatas, peneliti ingin mengetahui arti penting pelasanaan ritus gawe pati itu sendiri bagi masyarakat Dusun Bayan Beleq hingga membuat mereka masih gigih 
mempertahankan eksistensi ritus gawe pati hingga praktik keagamaan lainnya.

\section{Pokok Permasalahan}

Sesuai dengan latar belakang di atas, maka permasalahan dapat dirumuskan sebagai berikut:

1. Bagaimana pelaksanaan ritus gawe pati pada masyarakat Wetu Telu di Dusun Bayan Beleq?

2. Bagaimana eksistensi ritus gawe pati pada masyarakat Wetu Telu di Dusun Bayan Beleq?

\section{Tujuan Penelitin}

Adapun tujuan yang ingin dicapai dari penelitian ini adalah sebagai berikut :1) Untuk mengetahui pelaksanaan ritus gawe pati pada masyarakat Wetu Telu di Dusun Bayan Beleq. 2) Untuk mengetahui eksistensi ritus gawe pati pada masyarakat Wetu Telu di Dusun Bayan Beleq

\section{Metode Penelitian}

Penelitian ritus Gawe Pati ini merupakan penelitian etnografi yang bersifat kualitatif. Penentuan informan menggunakan teknik purposive sedangkan pengumpulan data menggunakan teknik observasi partisipasi, wawancara mendalam serta studi pustaka. Teknik analisis yang digunakan dalam penelitian ini adalah teknik analisis kualitatif.

Adapun tahapan dalam menganalisis data yakni dimulai dengan reduksi selanjutnya penyajian data dan yang terakhir adalah penarikan kesimpulan. Reduksi data meliputi berbagai kegiatan, yakni penyeleksian, pemfokusan, penggolongan, pembuatan pola, foto dokumentasi untuk situasi atau kondisi yang memiliki makna subyektif, kutipan wawancara yang memiliki makna subyektif, dan catatan reflektif (Soekanto, 2009).

\section{Hasil dan Pembahasan}

\subsection{Pelaksanaan Ritus Gawe pati}

Setiap orang yang ingin mengikuti prosesi pelaksanaan gawe pati, dianjurkan memakai pakaian adat, minimal dodot (kain pelapis pinggang, terkadang dapat diganti dengan sarung), dan sapu' (ikat kepala) untuk laki-laki dan kain hitam untuk wanita. Sebelum memandikan mayat, alat yang harus disiapkan meliputi: Kain warna putih (mori), untuk membungkus mayat, kain batik (jarik), untuk menutupi mayat, keranda dari bambu, untuk mengotong mayat, dan air untuk memandikan mayat. Adapun alat pelengkap upacara gawe pati antara lain: Sesajen, kemenyan, brem, sirih dan pinang, tembakau, perlengkapan untuk memandikan mayat, perlengkapan untuk mengkafani (membungkus) mayat, perlengkapan untuk pemakaman mayat, dan bunga-bunga untuk nyekar (ditabur di kuburan)

Bagi orang yang meninggal waktu lingsiran (waktu setelah zuhur) dimakamkan keesokan harinya tetapi diberikan boreh (seperti lulur tradisional) lalu mandi kambalkan ( mandi biasa) oleh keluarga terdekat baru kemudian oleh para kyai termasuk Penghulu dilanjutkan dengan pembacaan Lontar Chandra Kirana untuk menghibur keluarga yang meninggal. Keesokan harinya dilanjutkan dengan Trek Ules (memotong kain kafan) berjumlah ganjil sesuai kemampuan keluarga yang dilakukan oleh Penghulu atau Kyai lainnya seperti Ketib, Lebe, dan Mudim serta orang lain yang dianggap mampu (Sudirman,dkk, 2004).

Pelaksanaan gawe pati dimulai setelah dilakukannya penguburan yang diawali dengan Selamet Gumi Nyusur Tanak, kemudian dilanjutkan dengan, nelung pada hari ketiga, mituq pada hari ketujuh, nyiwak yaitu perayaan hari kesembilan, matang puluh pada hari keempat puluh, nyatus pada hari 
keseratus, dan nyiu sebagai penutup prosesi ritus gawe pati pada hari keseribu.. Masing-masing acara memilliki cara dan fungsi tertentu untuk orang yang meninggal. Selamet Gumi Nyusur Tanak dimulai setelah dilakuknnya trek ules oleh Kyai atau disaat orang yang meninggal akan dimandi sucikan.

Masyarakat Dusun Bayan Beleq membedakan perlakuan bagi mereka yang meninggal di luar batas kuta (wilayah) dusun. Mereka percaya bahwa yang meninggal diluar kuta akan membawa penyakit atau malapetaka. Hal ini menjadi alasan untuk diadakannya selamatan mengasuh. Sebelum dibawa ke dalam kuta, anggota keluarga harus melakukan ritual pembersihan yaitu dengan mengorbankan hewan seperti sapi atau kerbau untuk acara periapan mengsuh saat para Kyai berdo'a untuk keselamatan kuta.

\subsection{Eksistensi Ritus Gawe Pati}

Seiring berjalannya waktu, sejak tahun terakhir ini perayaan gawe pati dirasakan selalu dilakukan jika ada keluarga yang meninggal walaupun terdapat jangka waktu pelaksanaan. Perubahan dalam pelaksanaan gawe pati membuat ritus ini berubah, awalnya sebelum tahun 2000an proses gawe pati masih dilakukan secara besar-besaran tanpa ada jangka waktu pelaksanaan. Namun sekarang terdapat jangka waktu pelaksanaan karena masyarakat mengaku harus mengumpulkan biaya dulu atau menunggu acara gawe pati yang dilakukan secara bersama-sama dengan warga yang telah meningagal keluarganya untuk patungan biaya pelaksanaan.

Masyarakat cukup melakukan pesilaaan Kyai dan zikiran di rumah secara sederhana jika belum mampu. Tidak hanya itu, dahulu jika ada keluarga yang meninggal di luar kuta maka harus dilakukan selamatan mengasuh dan tidak boleh ditunda karena harus dikuburkan di kuburan dalam kuta, namun sekarang selamatan mengasuh tidak diwajibkan jika tidak mampu, mereka cukup menitipkan keluarga yang meninggal untuk dikuburkan atau dilakukan gawe pati di luar kuta.

Masyarakat lebih mementingkan inti dari gawe pati tersebut, yaitu sampainya arwah orang yang telah meninggal ke alam halus dan berada di sekitar leluhur. Perubahan yang cukup mendasar tersebut membuat gawe pati lebih bersifat terbuka untuk orang dari manapun, tidak hanya terbuka untuk keluarga, dan para Kyai contohnya saja pada proes pengkafanan mayat yang sebenarnya hanya boleh dilakukan oleh Para Kyai dan disaksikan oleh keluarga, sekarang ini siapa pun dapat menyaksikannya sehingga hal ini mendorong ritus gawe pati berkembang hingga prosesnya dapat dilakukan oleh semua golongan masyarakat walaupun hingga saat ini Kyai adat seperti Penghulu masih memegang peranan yang penting dalam segala hal proses gawe pati. Tidak hanya itu namun yang masih sangat kental dari gawe pati yaitu adanya lekesan, kemenyan, dan brem.

Pada setiap prosesi selalu disertai dengan lekesan dan kemenyan untuk mengundang leluhur dan sebagai makanan leluhur ketika menghadiri setiap prosesi gawe pati. Setiap acara periapan, makanan akan disuguhkan menggunakan sampak atau meja kecil terbuat dari tanah dan ditutup menggunakan tebolak yaitu penutup makanan berbentuk setengah lingkaran terbuat dari bambu. Makanan periapan untuk Kyai yang disiapkan disampak selalu berjumlah ganjil karena manusia meninggal dalam keadaan ganjil atau sendiri. Berbeda denagn sampak yang disediakan untuk periapan gawe urip 
berjumlah genap karena manusia hidup berdampingan dan berpasang-pasangan.

Jadi dalam gawe pati, adat untuk mengundang leluhur dan saling mengundang serta bertemu dan makan bersama dalam periapan merupakan ciri yang khas. Masyarakat Desa Bayan sekarang ini seringkali hanya mengambil inti pokok tersebut dibanding dengan landasan dasar yang melatar belakangi munculnya gawe pati tersebut. Gawe pati muncul karena keyakinan orang terdahulu bahwa arwah tidak akan sampai pada alam halus yang baik yaitu syurga jika keluarga tidak menebus dosa yang telah dilakukan si mati selama ia hidup melalui persembahan hewan kurban, aik mel-mel ato pun aik wangi.

Peran leluhur pun tidak dilupakan sebagai perantara penitipan orang yang baru meninggal untuk diantarkan menuju Tuhan dan disiapkan untuk memulai kehidupannya yang baru di alam halus. Namun, Unsur religius dan unsur magis tersebut sudah tidak terlalu kental dirasakan walaupun sesaji untuk pemanggilan leluhur masih tetap dilakukan. Masyarakat Desa Bayan kini lebih menekankan esensi gawe pati sebagai media untuk mengantar arwah yang baru meninggal saja.

Namun justru oleh hal tersebut, tradisi gawe pati menjadi lebih terbuka bagi setiap orang dalam kaitannya dengan keyakinan agama. Perubahan prosesi tersebut membuat gawe pati memiliki kelonggaran bagi setiap warga, berkaitan dengan waktu dan proses pelaksanaannya. Mereka dapat mengikuti semua proses melaksanakan gawe pati baik itu masyarakat Islam Wetu Telu maupun warga Islam lainnya yang berada di luar Bayan untuk menjalin serta menjaga ikatan kekerabatan yang mereka miliki.

\subsection{Faktor Eksistensi Ritus Gawe Pati}

Beberapa faktor internal yang mendukung eksistensinya ritus gawe pati hingga sekarang yaitu:

a. Kelonggaran dalam pelaksanaan

Berdasarkan pengamatan dan analisis peneliti, pelaksanaan ritus gawe pati dilaksanakan seadanya dan tidak dipaksakan jika tidak mampu namun menunggu melakukan secara bersamasama dengan warga lainnya. Tidak ada ketentuan dalam penyelenggaran gawe pati berkaitan dengan hidangan periapan dan jumlah tamu yang diundang karena yang terpenting menggunakan Kyai berjumlah ganjil. Kelonggaran tersebut membuat masyarakat Wetu Telu tidak terbebani secara ketat oleh ritus gawe pati. Masyarakat dapat melaksanakan secara massal dengan warga lainnya sehingga membuat ritus gawe pati tersebut dapat terus berkembang keberadaannya dalam masyarakat.

b. Kebutuhan untuk sangkep (berkumpul) Masyarakat Desa Bayan sangat menjunjung ikatan kekerabatan serta silaturrahmi. Mereka selalu mengadakan sangkep (pertemuan) antar warga agar mereka selalu kompak dan rukun dalam bertetangga. Hal ini menjadi salah satu keunikan Desa Bayan, setiap ada acara selalu akan dijumpai masing-masing perwakilan dari satu rumah untuk menghadiri sangkep. Gawe pati merupakan salah satu ritus yang dilakukan secara bergotong royong antar sesama warga dusun. Biasanya gawe pati dijadikan media juga untuk sangkep antar warga karena ritus ini membutuhkan persetujuan oleh banyak orang walaupun tetap tergantung keluarga si mati. Keluarga yang berada jauh dari dusun bahkan luar Desa Bayan akan datang ke Bayan untuk mengikuti upacara gawe pati. Untuk itulah gawe pati merupakan media paling cepat untuk sangkep warga 
karena semua warga akan bertemu di sini terutama pada hari pertama dan hari matang puluh.

c. Media Penghormatan terhadap Leluhur dan Jenazah

Masyarakat Wetu Telu menganggap kematian adalah sesuatu yang sangat religius karena menyangkut leluhur dalam setiap prosesnya tidak hanya mengenai do'a untuk si mati. Setiap ritus gawe pati merupakan ritus yang sangat panjang dan berhubungan langsung dengan leluhur masyarakat Desa Bayan dan merupakan momen untuk mereka menunjukkan seberapa ingatnya dan berterima kasihnya mereka terhadap leluhur yang telah menjamin dan mensejahterakan hidup mereka.

Selain faktor internal, terdapat faktor eksternal yang mendukung adanya ritus gawe pati. Faktor eksternal adalah faktor pendukung dari pemerintah Lombok Utara maupun dari Provinsi NTB yang masih ingin untuk tetap melestarikan budaya Wetu Telu termasuk semua ritus keagamaan yang dijalani masyarakat Wetu Telu sebagai cagar budaya Lombok (Noor, dkk, 2004). Lembaga Pemerintahan dan Dinas yang ada di Lombok selalu melakukan pantauan terhadap masyarakat penganut Wetu Telu untuk memberikan bantuan ketika akan digelar acara adat maupun bantuan untuk renovasi Masjid Kuno dan Bale Kampu.

\subsection{Faktor Tantangan Ritus Gawe Pati}

Faktor-faktor penghambat eksisteni Wetu Telu termasuk gawe pati yaitu:

\section{a. Biaya yang besar}

Semua ritus yang dilakukan oleh masyarakat Desa Bayan memerlukana biaya yang besar. Namun semuanya dilakukan secara bersama-sama dan saling membantu begitupun dengan ritus gawe pati. Ketika ada warga yang melakukan ritus gawe pati maka warga lain akan membantu dan jika kurang mampu membiayai ritus gawe pati maka pelaksanaan ritus akan tertunda jika biaya yang dikumpulkan masyarakat masih belum mencukupi. Biaya yang besar tersebut sebenarnya kendala mendasar dalam pelaksanaan gawe pati. Mereka cenderung menunggu secara massal meskipun tidak semua rangkaian gawe pati bisa dikerjakan secara massal. Contohnya ritual Nyiu, pada tahap ini dianggap sebagai puncak perayaan gawe pati terutama untuk masyarakat Dusun Bayan Timur.

b. Desakan Gerakan Pemurnian Agama

Faktor penghambat eksistensi gawe pati yang paling utama adalah adanya desakan-desakan dari gerakan pemurnian agama Islam mainstrem yang marak di Pulau Lombok. Tidak hanya gawe pati namun keyakinan mereka tentang Islam Wetu Telu sudah agak sedikit tergerus oleh adanya beberapa kelompok-kelompok yang mulai memasuki Desa Bayan dan banyak menetap di sekitar Desa Bayan.

Penduduk Desa Bayan juga sudah mulai mengikuti organisasi islam dan bahkan ada juga yang telah menjadi pengurus cabang organisasi Islam tersebut. Hal ini dikarenakan banyak dari pemuda Bayan yang sudah mulai keluar desa untuk menuntut ilmu dan belajar agama Islam hingga mereka mengikuti organisasi-organisai keislaman yang praktinya sedikit berbeda dengan apa yang masyarakat Wetu Telu lakukan,

Wet agama memang tidak mempermasalahkannya asalkan masyarakat menghormati masyarakat Bayan lainnya. Namun terkadang orang luar Bayan seperti orang Lombok Timur, Lombok Tengah dan Lombok Barat yang sering melakukan ziarah makam tidak menggunakan pakaian yang telah ditetapkan oleh adat. Hal ini menimbulkan kecemburuan sosial kepada 
warga Desa Bayan dan cenderung dicontoh oleh teruna-teruni Desa Bayan. Ketika mereka melakukan ziarah makam, teruna-teruni Bayan hanya menggunakan kain biasa seperti kesehariannya.

c. Pergeseran Orientsi Nilai

- Nilai yang terlihat sangat berubah yaitu nilai menjaga adat dan budaya. Masyarakat yang ada di Desa Bayan maupun masyarakat di luar Desa Bayan yang tergolong Wetu Telu sudah jarang terlihat menggunakan kain adat warna hitam jika mengunjungi kerabat yang meninggal. penggunaan kain hitam menyimbolkan rasa berduka namun sudah banyak dari warga yang menggunakan kain berwarna lain untuk mengunjungi kerabat yang meninggal.

\subsection{Fungsi Gawe Pati}

Fungsi-fungsi gawe pati adalah:

a. Fungsi Religius

Gawe pati merupakan rangkaian ritual untuk arwah yang telah meninggal. Sebenarnya dalam gawe pati ini merupakan acara mengundang leluhur untuk menjemput arwah orang yang telah meninggal untuk dituntun menuju alam halus. Setiap rangkaian ritus gawe pati ini selalu melibatkan kosmologis yaitu leluhur. Kedudukan leluhur sangat penting di masyarakat Wetu Telu karena penghubung mereka dengan Tuhan. Melalui gawe pati ini semua leluhur diundang pada setiap acara mulai dari selametan mengasuh jika diperlukan, selamat gumi nyusur tanak hingga nyiu karena mereka diibaratkan sebagai pelayan Tuhan untuk mensejahterahkan keturunannya yang masih hidup maupun yang baru meninggal.

b. Fungsi menjaga ikatan kekerabatan

Melalui ritus tgawe pati masyarakat mengundang para kerabat dan saudara untuk berkunjung dan bersilaturahmi ke rumah duka. Melalui ritus gawe pati pula banyak saudara yang bertemu, khususnya kaum kerabat yang berada di wilayah jauh dari daerah Kecamatan Bayan dan sekitarnya. Masyarakat Dusun Bayan Beleq mengatakan bahwa gawe pati merupakan peristiwa yang membuat mereka bisa bertemu dengan para kerabat dan sanak saudara. Bentuk silaturahmi yang terjadi ketika gawe pati tidak jauh berbeda dengan bentuk silaturahmi ketika Idul Fitri.

c. Fungsi menjaga warisan budaya

Masyarakat Desa Bayan sangat paham mengenai tradisi budaya warisan leluhur. Mereka mengerti bahwa warisan budaya tersebut harus selalu terjaga keberadaanya. Masyarakat Desa Bayan menganggap bahwa ritus gawe pati adalah warisan yang memiliki nilai yang positif bagi mereka. Walaupun banyak terjadi modifikasi dalam gawe pati namun mereka berharap anak cucu mereka mampu meresapi makna yang terkandung dalam setiap ritual yang diadakan dan mampu menghormati leluhur mereka yang telah menjamin keejahteraan hidup mereka. Masyaakat meyakini bahwa dengan mengajarkan bahkan melibatkan langsung anak cucu Bayan dalam acara gawe pati maka masyarakat akan secara langsung meresapi bagaimana urutan proses agar anak cucu masyarakat Bayan tidak sembarangan melakukan ritus gawe pati.

\section{Kesimpulan}

Berdasarkan pembahasan dan analisis data mengenai eksistensi ritus gawe pati pada masyarakat Wetu Telu Dusun Bayan Beleq dapat disimpulkan sebagai berikut. Pertama, masyarakat Wetu Telu merupakan masyarakat yang mengakui Tuhan namun mempercayai adanya leluhur dengan menganut filosofi peralihan hidup. Masyarakat Wetu Telu percaya bahwa leluhur mampu jadi perantara antara orang Bayan dengan Tuhan. Karena alasan ini leluhur selalu diundang karena berkah yang dapat 
mereka berikan begitupun untuk gawe pati.

Ritus gawe pati merupakan sebuah ritus untuk mengantarkan arwah keluarga yang baru meninggal melalui perantara pemanggilan leluhur yang akan menjemput arwah tersebut untuk menuju ke alam halus. Rangkaian gawe pati yaitu selametan mengasuh jika meninggal di luar kuta, kemudian ketiga (nelung), hari ketujuh (mituk), hari kesembilan (nyiwak), hari keempat puluh (matang puluh), keseratus (nyatus), hingga hari keseribu (nyiu).

Gawe pati yang terjadi sekarang ini sudah banyak mengalami perubahan yang disebabkan oleh beberapa permasalahan yang timbul diantara masyarakat seperti banyaknya biaya, kemudian terjadinya percampuran pelaksanaan antara adat dan agama mainstream sehingga gawe pati menjadi agak sedikit terbuka untuk umum. Masyarakat masih mempertahankan gawe pati dan Wetu Telu secara umum karena memiliki fungsi yang cukup penting dalam kehidupan sosial mereka terutama untuk keluarga mereka yang telah meninggal. Fungsi-fungsi yang tertanam dalam gawe pati tidak terlepas dari faktor-faktor pendorong eksisnya gawe pati hingga sekarang dengan perubahan yang ada. Namun, walaupun fungsi-fungsi gawe pati tersebut masih penting untuk kepentingan hidup mereka namun terdapat tantangan yang bisa secara perlahan melunturkan nilai-nilai yang terkandung dalam gawe pati. tidak hanya gawe pati namun konsep Wetu Telu yang mereka yakini sejak lama akan perlahan menghilang jika mereka terlambat menyadari faktor penghambat tersebut.

\section{Saran}

Berdasarkan hasil penelitian dan pengamatan yang telah dilaksanakan mengenai gawe pati dan kehidupan sosial masyarakat Desa Bayan, peneliti memberikan saran yaitu:

1. Masyarakat Dusun Bayan Beleq hendaknya semakin menanamkan nilai penting gawe pati untuk generasi muda sehingga keberadaan Wetu Telu dan ritus gawe pati dikemudian hari masih bisa dilanjutkan.

2. Masyarakat hendaknya bisa mempertahankan kebudayaan yang menjadi ciri khas masyarakat Wetu Telu walaupun banyak faktor penghambat untuk mempertahankan ritus-ritus peralihan dan konsep kehidupan

3. Pemerintah sudah seharusnya menghargai kebudayaan minoritas dan melestarikan kebudayaaan masyarakat Wetu Telu serta mendukung jika memang dianggap bermanfaat untuk menjaga kearifan ekologi tanpa melihat keuntungan yang dihasilkan.

\section{Daftar Pustaka}

Budiwanti, Erni. 2000. Islam Sasak: Wetu Telu Versus Waktu Lima. Yogyakarta: LKis .

Ghazali, AdengMuchtar. 2011. Antropologi Agama (UpayaMemahamiKeragamanKepercaya an, Keyakinan, dan Agama. Bandung: Alfa Beta.

Noor, Mohammad, dkk. 2014. Visi Kebangsaan Religius. Jakarta: Komplek Perguruan NW.

Soekanto, Soekanto. 2009. Sosiologi Suatu Pengantar: Edisi Baru. Jakarta. Rajawali Pers.

Sudirman, dkk. 2014. Studi Sejarah dan Budaya Lombok. Lombok: Pusakanda. 
Umam, Fawaizul, dkk. 2006.

Membangun Resistensi Merawat Tradisi:

Modal Sosial Komunitas Wetu Telu.

Mataram: LKIM. 